\title{
Exposome and Skin: Part 1. Bibliometric Analysis and Review of the Impact of Exposome Approaches on Dermatology
}

\author{
Manuel Molina-García (1) · Corinne Granger (1) · Carles Trullàs (1) · \\ Susana Puig (D)
}

Received: November 11, 2021 / Published online: February 3, 2022

(c) The Author(s) 2022

\begin{abstract}
Introduction: Most skin disorders, such as atopic dermatitis, psoriasis, skin cancer or age-related skin issues, are the result of a complex interaction between genetic and environmental factors over time. As an external organ, the skin provides the opportunity to study the link between exposure to the environment and several specific biological responses using an
\end{abstract}

M. Molina-García · S. Puig

School of Medicine and Health Science, University of Barcelona (UB), 143 Casanova, 08036 Barcelona, Spain

M. Molina-García · S. Puig

Institut d'Investigacions Biomèdiques August Pi i

Sunyer (IDIBAPS), Barcelona, Spain

M. Molina-García · S. Puig ( $₫)$

Melanoma Unit, Dermatology Department,

Hospital Clinic of Barcelona, Villarroel 170, 08036

Barcelona, Spain

e-mail: spuig@clinic.cat; susipuig@gmail.com

M. Molina-García

e-mail: manmolina@clinic.cat;

manuel.molina@ub.edu

C. Granger · C. Trullàs

Innovation and Development, ISDIN, S.A., 33

Provençals, 08019 Barcelona, Spain

\section{S. Puig}

Centro de Investigación en Red de Enfermedades Raras (CIBERER), Instituto de Salud Carlos III,

Barcelona, Spain exposome approach. The aim of this review was to identify the state of the art of exposome approaches and elucidate the impact of the new era of exposomics on dermatology.

Methods: Two parallel and independent bibliometric analyses were conducted based on documents extracted from the Core Collection and the Science Citation Index Expanded (SCIExpanded) databases from the Clarivate Analytics' Web of Science (WOS) platform by using the following search terms "exposome" and "skin exposome". In both searches, we used the topic field that includes title, abstract, author keywords and keywords plus terms and the following filters: "English language" and all documents published up to 30 September 2021. We further analysed and interpreted documents extracted in plain text format.

Results: Based on the defined searches, 910 documents were identified as being related to "exposome" and 45 as being related to "skin exposome". Environmental sciences and toxicology were the most impacted research areas, and aging, cancer and respiratory allergies were the most documented diseases while, surprisingly, dermatology was much less impacted. Krutmann et al. were the pioneers in implementing this new concept in dermatology with publication of "The skin aging exposome" in 2017 (J Dermatol Sci. 2017;85:152-61). After this tipping point, the number of publications in dermatology evaluating the impact of 
exposome factors in many skin disorders has steadily increased.

Conclusions: Exposome studies are rapidly attracting interest in dermatology. The results of these studies will undoubtedly improve our understanding of why and under which circumstances some individuals develop skin disorders and help design tailored prevention strategies for patients suffering from these disorders.

Keywords: Bibliometric analysis; Dermatology; Environmental factors; Epidemiology; Exposome; Exposure; Omics; Skin

\section{Key Summary Points}

Skin disorders are highly influenced by exposure to several environmental, lifestyle and internal factors that act on the genome, producing a specific biological response in the body.

The epidemiologist Christopher P. Wild coined the term "exposome" in 2005 to mean the lifelong totality of environmental exposure (including lifestyle factors) from conception.

Many exposome studies have been published in the fields of environmental sciences and toxicology, but dermatology has been much less impacted.

After the appearance of the pioneer publication in the Journal of Dermatological Science entitled "The skin aging exposome" in 2017, the number of publications relating to dermatology has increasingly grown.

Exposome studies might contribute to our understanding of the aetiology of skin disorders and help in the design of tailored preventive strategies for patients suffering from these disorders.

\section{INTRODUCTION}

Most skin disorders, such as atopic dermatitis (AD), psoriasis, skin cancer or age-related skin issues, are the result of a complex relationship between genetic and environmental factors which interact with each other over time [1-4]. To understand this complex interaction, it is crucial to know why and under which circumstances some individuals develop these skin disorders. However, the rapid progress that has been made in genetics in the last few decades with the Human Genome Project has tilted the genetic-environment balance in favour of the former [5-7]. The epidemiologist Christopher P. Wild realized the urgent need to develop methods for assessing an individual's exposure and coined the term "exposome" in 2005 to mean the lifelong totality of environmental exposure (including lifestyle factors) from conception [8]. Clearly, the study of the exposome is a great challenge due to its high variability and dynamism and its full characterization would require repeated measures that capture exposure over a series of extended periods. Since many exposures will leave their fingerprint, the new "omics" technologies could help to tackle this great challenge of assessing exposure [9]. Despite the exposome concept first being introduced in the field of exposure assessment, it should also be extended to explain how our bodies respond to environmental pressures, including epigenetic modifications and complex biochemical reactions. Accordingly, the definition has been widened to: "The cumulative measure of environmental influences and associated biological responses throughout the lifespan, including exposures from the environment, diet, behaviour and endogenous processes" [10]. The skin is the outermost and largest organ, comprising a $2-\mathrm{m}^{2}$ interface that is constantly exposed to environmental factors, such as solar radiation, climate and pollution, whose effects have been studied and described in depth [11-13]. The effects of lifestyle factors such as, for example, nutrition or tobacco use have also been well described [14, 15]. Despite being an external organ, the skin is also exposed to endogenous stimuli, such as hormones [16], 
microbiome [17] or even psychological stress [18]. The aim of our study was to identify the state of the art of exposome approaches and to elucidate what the impact of the new era of exposomics has been on dermatology. Here we present two bibliometric analyses of the exposome and skin exposome literature. We first present a quantitative analysis characterizing the body of literature, including annual scientific production and citations, the most impacted research areas, the salient authors and their intellectual roots and then we present a summary of all skin exposome publications.

\section{METHODS}

The bibliometric analyses were conducted as follows: (1) definition of the search criteria, including terms, language, period and database selection; (2) data extraction in plain text format; (3) data analysis, visualization and interpretation.

\section{Search Strategy and Database}

The search was conducted in the Core Collection and Science Citation Index Expanded (SCIExpanded) databases from the Clarivate Analytics Web of Science (WOS) platform. We conducted two separate and parallel searches in September 2021, one related to the exposome and the other related to the skin exposome. Accordingly, we used the term "exposome" for the first search and the term "skin exposome" for the second one. We used a topic field which includes title, abstract, author keywords and keywords plus terms and the following filters: "English Language" and publication date up to 30 September 2021 for both searches.

\section{Data Extraction}

All documents related to the search term "exposome" were retrieved for further analysis, and those related to the search term "skin exposome" were manually selected to ensure search accuracy. We extracted the full record data and cited references in plain text format.

\section{Data Analysis and Visualization}

Based on the extracted data, two bibliometric analyses were performed using R software version 1.3.1056 [19] and the bibliometrix $R$ package developed by Aria and Cucurrullo [20]. For the construction of maps of co-occurrence analysis of author keywords, we used the VOS Viewer software (version 1.6.15; Leiden University Centre for Technology Studies, Leiden, the Netherlands) [21].

This article is based on previously conducted studies and does not involve any new studies of human or animal subjects performed by any of the authors.

\section{RESULTS}

\section{Evolution of the Exposome Concept and Its Impact on Dermatology}

Based on the defined searches, we found 910 documents related to "exposome" and 45 related to "skin exposome". We retrieved all of the documents related to "exposome" and manually selected and retrieved 26 documents related to "skin exposome". There has been a signficant increase in scientific interest in the exposome concept since its definition in 2005, as evidenced by the number of publications (Fig. 1). In comparison, interest in this concept in dermatology has come later and involved fewer publications. As shown in the tree map of the top ten most frequent WOS research areas (Fig. 2), the top three research areas with the largest number of publications were "Environmental Sciences", "Public Environmental Occupational Health" and "Toxicology", with 253, 227 and 131 entries, respectively. Exposome-related concepts have also been exported to other disciplines, such as "Biochemistry Molecular Biology", "Chemistry Analytical", "Genetics Heredity", "Immunology", "Biochemical Research Methods", "Respiratory System" and "Allergy", among many others. Twenty-seven entries were classified in the "Dermatology" field, indicating that this discipline has been much less impacted by the exposome. 


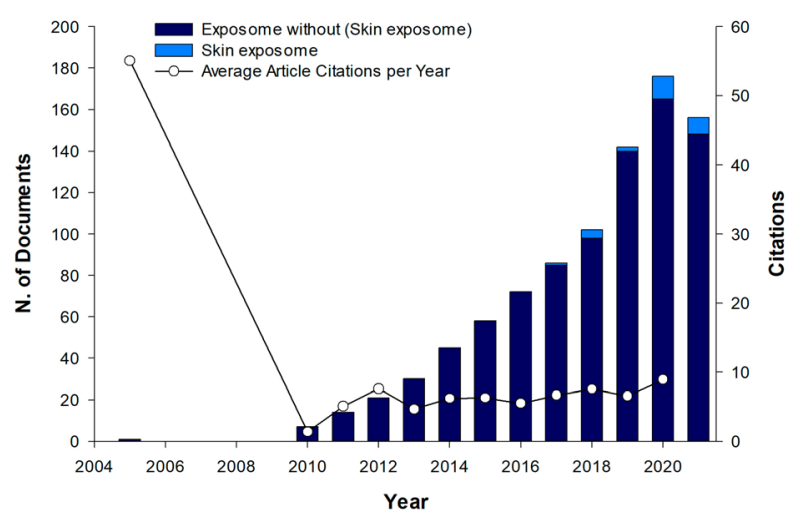

Fig. 1 Annual scientific production (column graph and left ordinate axis) and average number of article citations per year (line scatter graph and right ordinate axis) of the "exposome" and "skin exposome" documents obtained from the Clarivate Analytics Web of Science (WOS) platform.
The average number of article citations per year was calculated as the total sum of citations of all articles divided by the number of articles published in that year, then divided by the number of citable years

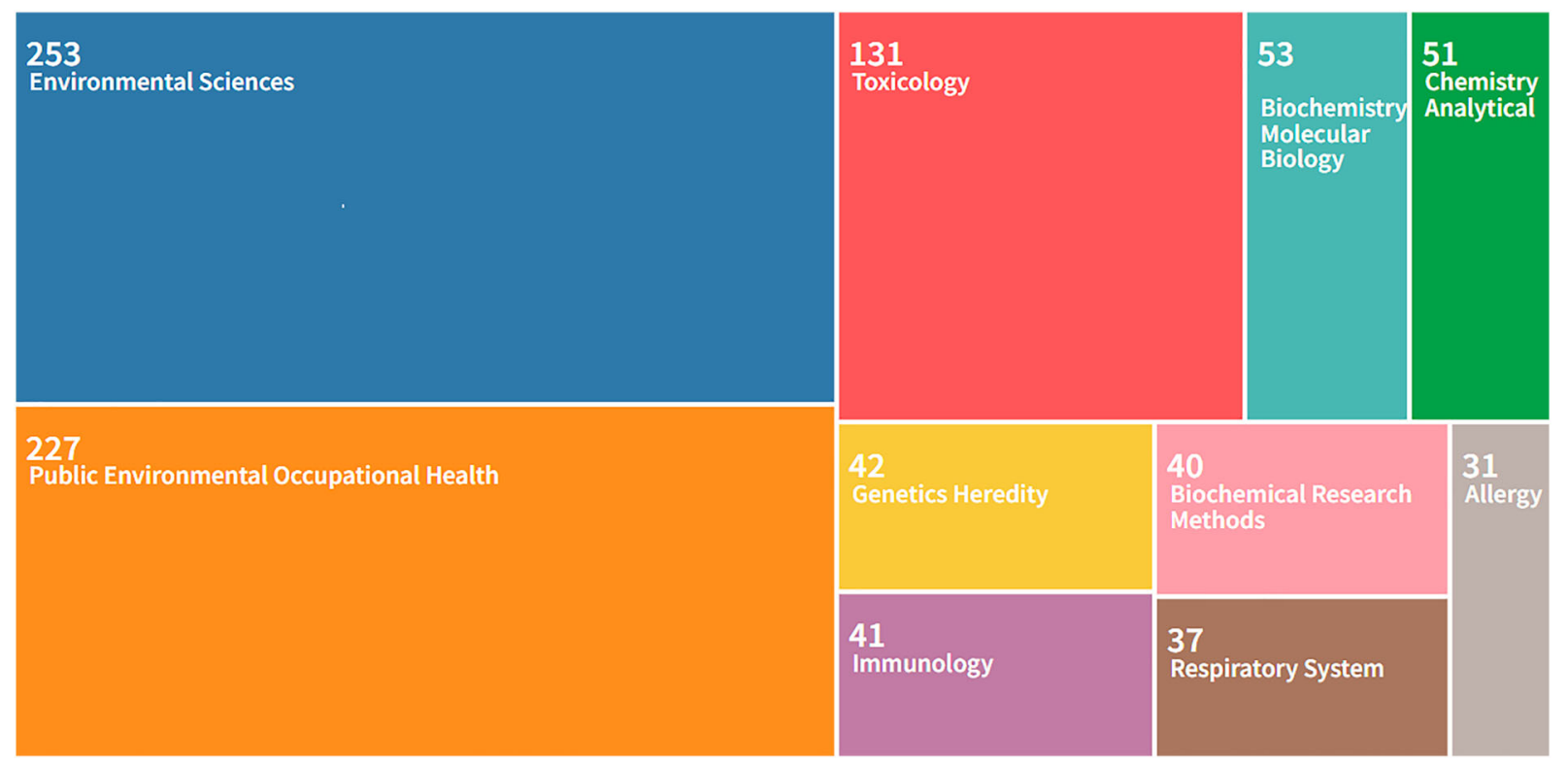

Fig. 2 Tree Map chart of the most impacted WOS categories

\section{Co-Occurrence Analysis of Author Keywords in the 910 Documents Associated to "Exposome"}

The density map of co-occurrence analysis of author keywords (Fig. 3), includes nine clusters of 94 relevant keywords with a total link strength of 526.5. In this map, we found that the main author keywords are "exposome", "environment", "metabolomics", "air pollution", "biomarkers", "epidemiology", "pregnancy" and "asthma", among many others. The most extensive clusters were related to aging, gut disorders, $\mathrm{AD}$, biomonitoring and exposure assessment, respiratory allergies and cancer, among others. 


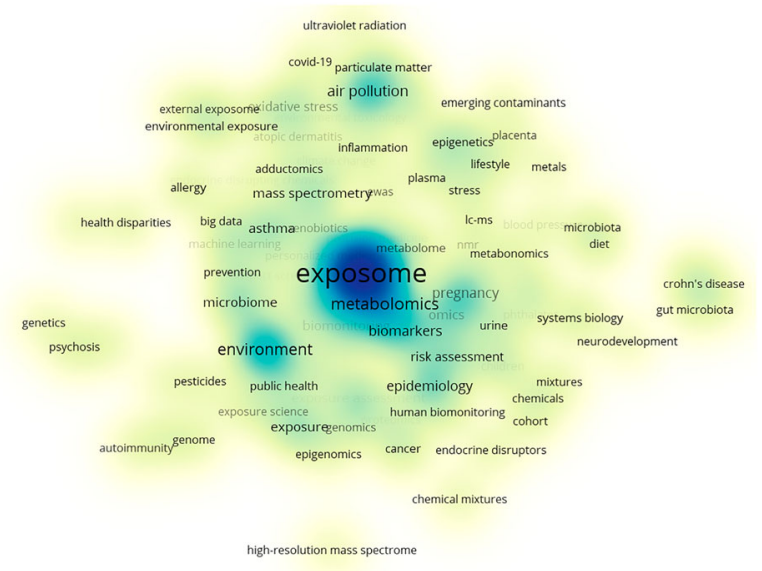

Fig. 3 Density visualization map of co-occurrence analysis of author keywords of the "exposome" documents. Counting method: fractional counting (the weight of a link is fractionalized). The relatedness of items was

\section{Review of the Exposome Implementation in Dermatology}

The implementation of the exposome concept in dermatology started about 5 years ago and is growing rapidly (Table 1) [22-47]. The overall aim of most studies has been to evaluate the combined and cumulative effects of the exposome factors on skin health. In the following subsections we provide an update and general description of the skin exposome publications structured by pathology.

\section{Skin Aging}

Krutmann et al. were the pioneers in implementing this new concept in the field of dermatology with the publication entitled "The skin aging exposome" in 2017. They studied the role of exposome in skin aging and proposed the following categories of environmental factors: (1) sun radiation, ultraviolet radiation (UVR), visible light and infrared radiation; (2) air pollution; (3) tobacco smoke; (4) nutrition; (5) a number of less well-studied, miscellaneous factors; and (6) cosmetic products [47]. Based on their results, they concluded that UVR, smoking and pollution were the three main factors that induce skin aging [47]. Since this review, there have been several publications, including an in vitro study of the role of a mineralized determined based on the number of documents in which they occur together. Minimum number of occurrences of a keyword: 5

thermal water product to counteract the effects of the exposome on skin aging [44] and its possible role in improving facial skin quality when combined with hyaluronic acid in vivo [42]. A cross-sectional epidemiological study analysed the impact of various factors on the degree of skin aging among the Spanish population [34]. Khmaladze et al. reviewed the impact of environmental, lifestyle and internal factors on skin health and skin aging and constructed a digital model to identify and optimize skin treatment options based on external triggers [38]. Later studies have assessed how the impact of cigarette smoke alters the skin barrier [30], and what type of daily photoprotection is needed to mitigate extrinsic skin aging [26]. Clearly, skin aging has been the most impacted pathology by the exposome concept in the field of dermatology.

\section{Atopic Dermatitis}

Regarding AD, Ghosh et al. explored the subphenotypes/endotypes that result from the complex interplay between intrinsic and extrinsic factors through a multi-omics approach, integrating data from different layers, such as the microbiome, proteome, lipidome, transcriptome, epigenome, exposome and genome, unravelling new biological insights in the aetiology of this complex disease [43]. Cecchi 
Table 1 Skin exposome publications

\begin{tabular}{|c|c|c|c|c|c|}
\hline Study title & Year & $\begin{array}{l}\text { Total } \\
\text { number } \\
\text { of } \\
\text { citations }\end{array}$ & Journal & Disease(s) analysed & $\begin{array}{l}\text { Exposome factors } \\
\text { analysed }\end{array}$ \\
\hline $\begin{array}{l}\text { How to prevent skin damage from } \\
\text { air pollution part } 2 \text { : Current } \\
\text { treatment options [22] }\end{array}$ & 2021 & 0 & Dermatol Ther & $\begin{array}{l}\text { Acne, airborne allergic } \\
\text { contact dermatitis, } \\
\text { AD, } \\
\text { dermatomyositis, } \\
\text { lupus erythematosus, } \\
\text { NMSC, rosacea and } \\
\text { skin aging }\end{array}$ & Pollution \\
\hline $\begin{array}{l}\text { Diet-related phototoxic reactions in } \\
\text { psoriatic patients undergoing } \\
\text { phototherapy: results from a } \\
\text { multicenter prospective study [23] }\end{array}$ & 2021 & 0 & Nutrients & $\begin{array}{l}\text { Phytophotodermatitis, } \\
\text { erythema }\end{array}$ & $\begin{array}{l}\text { Vegan, vegetarian } \\
\text { and omnivore } \\
\text { diet, NB-UVB }\end{array}$ \\
\hline $\begin{array}{l}\text { Exposome extrinsic factors in the } \\
\text { tropics: the need for skin } \\
\text { protection beyond solar UV } \\
\text { radiation [24] }\end{array}$ & 2021 & 0 & Sci Total Environ & - & $\begin{array}{l}\text { Solar UVR, air } \\
\text { pollution, air } \\
\text { temperature, } \\
\text { relative humidity } \\
\text { and ground level } \\
\text { ozone }\left(\mathrm{O}_{3}\right)\end{array}$ \\
\hline $\begin{array}{l}\text { Adult skin acute stress responses to } \\
\text { short-term environmental and } \\
\text { internal aggression from exposome } \\
\text { factors [25] }\end{array}$ & 2021 & 0 & $\begin{array}{l}\text { J Eur Acad } \\
\text { Dermatol } \\
\text { Venereol }\end{array}$ & - & $\begin{array}{l}\text { Environmental } \\
\text { (meteorological } \\
\text { factors, solar } \\
\text { radiation and } \\
\text { pollution) and } \\
\text { internal (acute } \\
\text { nutrition / } \\
\text { alcohol intake, } \\
\text { hormonal } \\
\text { variations, lack of } \\
\text { sleep, } \\
\text { psychosocial } \\
\text { stress) }\end{array}$ \\
\hline $\begin{array}{l}\text { Daily photoprotection to prevent } \\
\text { photoaging [26] }\end{array}$ & 2021 & 3 & $\begin{array}{l}\text { Photodermatol } \\
\text { Photoimmunol } \\
\text { Photomed }\end{array}$ & Skin aging & $\begin{array}{l}\text { Solar UVR, VL, } \\
\text { IRA and } \\
\text { pollution }\end{array}$ \\
\hline
\end{tabular}


Table 1 continued

\begin{tabular}{|c|c|c|c|c|c|}
\hline Study title & Year & $\begin{array}{l}\text { Total } \\
\text { number } \\
\text { of } \\
\text { citations }\end{array}$ & Journal & Disease(s) analysed & $\begin{array}{l}\text { Exposome factors } \\
\text { analysed }\end{array}$ \\
\hline $\begin{array}{l}\text { Impact of ultraviolet radiation and } \\
\text { exposome on rosacea: Key role of } \\
\text { photoprotection in optimizing } \\
\text { treatment [27] }\end{array}$ & 2021 & 1 & $\begin{array}{l}J \text { Cosmet } \\
\text { Dermatol }\end{array}$ & Rosacea & $\begin{array}{l}\text { UVR, VL, } \\
\text { pollution, } \\
\text { tobacco, } \\
\text { nutrition, stress, } \\
\text { heat, cleansers, } \\
\text { moisturizers, } \\
\text { sunscreens }\end{array}$ \\
\hline $\begin{array}{l}\text { The role of photoprotection in } \\
\text { optimizing the treatment of atopic } \\
\text { dermatitis }[28]\end{array}$ & 2021 & 0 & Dermatol Ther & $\begin{array}{l}\text { Atopic/contact } \\
\text { dermatitis }\end{array}$ & $\begin{array}{l}\text { UVR, vitamin } \mathrm{D} \text {, } \\
\text { sunscreens }\end{array}$ \\
\hline $\begin{array}{l}\text { SkinBug: an artificial intelligence } \\
\text { approach to predict human skin } \\
\text { microbiome-mediated metabolism } \\
\text { of biotics and xenobiotics [29] }\end{array}$ & 2021 & 0 & ISCIENCE & - & - \\
\hline $\begin{array}{l}\text { Impact of cigarette smoke on } \\
\text { physical-chemical and molecular } \\
\text { properties of human skin in an } \\
\text { ex vivo model [30] }\end{array}$ & 2020 & 1 & Exp Dermatol & Skin aging & Cigarette smoke \\
\hline $\begin{array}{l}\text { Clinical and biological impact of the } \\
\text { exposome on the skin [31] }\end{array}$ & 2020 & 11 & $\begin{array}{l}J \text { Eur Acad } \\
\text { Dermatol } \\
\text { Venereol }\end{array}$ & $\begin{array}{l}\text { Skin aging, } \mathrm{AD} \text {, } \\
\text { rosacea, acne, } \\
\text { psoriasis }\end{array}$ & $\begin{array}{l}\text { Solar radiation, } \\
\text { pollution, } \\
\text { hormones, } \\
\text { nutrition \& } \\
\text { psychological } \\
\text { factors }\end{array}$ \\
\hline $\begin{array}{l}\text { Skin exposome science in practice: } \\
\text { current evidence on hair } \\
\text { biomonitoring and future } \\
\text { perspectives [32] }\end{array}$ & 2020 & 1 & $\begin{array}{l}J \text { Eur Acad } \\
\text { Dermatol } \\
\text { Venereol }\end{array}$ & Hair damage & $\begin{array}{l}\text { Pollution and } \\
\text { microbiome }\end{array}$ \\
\hline $\begin{array}{l}\text { Environmental factors in epithelial } \\
\text { barrier dysfunction [33] }\end{array}$ & 2020 & 29 & $\begin{array}{l}\text { J Allergy Clin } \\
\text { Immunol }\end{array}$ & $\begin{array}{l}\mathrm{AD} \text {, other respiratory } \\
\text { disorders }\end{array}$ & $\begin{array}{l}\text { Allergens, } \\
\text { detergents, } \\
\text { tobacco, ozone, } \\
\text { pollution, } \\
\text { nanoparticles, } \\
\text { microplastic }\end{array}$ \\
\hline
\end{tabular}


Table 1 continued

\begin{tabular}{|c|c|c|c|c|c|}
\hline Study title & Year & $\begin{array}{l}\text { Total } \\
\text { number } \\
\text { of } \\
\text { citations }\end{array}$ & Journal & Disease(s) analysed & $\begin{array}{l}\text { Exposome factors } \\
\text { analysed }\end{array}$ \\
\hline $\begin{array}{l}\text { Study of the exposome ageing-related } \\
\text { factors in the Spanish population } \\
{[34]}\end{array}$ & 2020 & 3 & $\begin{array}{r}\text { Acta Derm } \\
\text { Venereol }\end{array}$ & Skin aging & $\begin{array}{l}\text { Solar radiation, } \\
\text { sunscreens, } \\
\text { cosmetics, } \\
\text { nutrition, water } \\
\text { intake, alcohol, } \\
\text { tobacco, stress } \\
\text { level, sleep } \\
\text { deprivation }\end{array}$ \\
\hline $\begin{array}{l}\text { The role of exposome in acne: results } \\
\text { from an international patient } \\
\text { survey [35] }\end{array}$ & 2020 & 10 & $\begin{array}{l}J \text { Eur Acad } \\
\text { Dermatol } \\
\text { Venereol }\end{array}$ & Acne & $\begin{array}{l}\text { Sun exposure, } \\
\text { humid or hot, } \\
\text { weather, } \\
\text { mechanical } \\
\text { factors, stress, } \\
\text { pollution, } \\
\text { nutrition, } \\
\text { nibbling, tobacco }\end{array}$ \\
\hline $\begin{array}{l}\text { Gut microbiota and nutrient } \\
\text { interactions with skin in psoriasis: } \\
\text { a comprehensive review of animal } \\
\text { and human studies [36] }\end{array}$ & 2020 & 3 & $\begin{array}{l}\text { World J Clin } \\
\text { Cases }\end{array}$ & Psoriasis & $\begin{array}{l}\text { Nutrition, } \\
\text { microbiome }\end{array}$ \\
\hline $\begin{array}{l}\text { Balance between health risks and } \\
\text { benefits for outdoor workers } \\
\text { exposed to solar radiation: an } \\
\text { overview on the role of near } \\
\text { infrared radiation alone and in } \\
\text { combination with other spectral } \\
\text { bands [37] }\end{array}$ & 2020 & 3 & $\begin{array}{c}\text { Int J Environ Res } \\
\text { Public Health }\end{array}$ & $\begin{array}{l}\text { Skin cancer, skin aging, } \\
\text { macular } \\
\text { degeneration }\end{array}$ & $\begin{array}{l}\text { Solar radiation } \\
\text { (IRA, UVB, } \\
\text { UVA, visible } \\
\text { light) }\end{array}$ \\
\hline $\begin{array}{l}\text { The skin interactome: a holistic } \\
\text { "genome-microbiome-exposome" } \\
\text { approach to understand and } \\
\text { modulate skin health and aging } \\
\text { [38] }\end{array}$ & 2020 & 2 & $\begin{array}{l}\text { Clin Cosmet } \\
\text { Investig } \\
\text { Dermatol }\end{array}$ & Skin aging & $\begin{array}{l}\text { UVR, blue light, } \\
\text { IRR, pollution, } \\
\text { climate, sleep, } \\
\text { exercise, } \\
\text { nutrition, mental } \\
\text { health, pre- and } \\
\text { probiotics, } \\
\text { cosmetics, } \\
\text { microbiome }\end{array}$ \\
\hline
\end{tabular}


Table 1 continued

\begin{tabular}{|c|c|c|c|c|c|}
\hline Study title & Year & $\begin{array}{l}\text { Total } \\
\text { number } \\
\text { of } \\
\text { citations }\end{array}$ & Journal & Disease(s) analysed & $\begin{array}{l}\text { Exposome factors } \\
\text { analysed }\end{array}$ \\
\hline $\begin{array}{l}\text { How to prevent skin damage from } \\
\text { air pollution. Part 1: exposure } \\
\text { assessment [39] }\end{array}$ & 2020 & 3 & Dermatol Ther & - & Pollution \\
\hline $\begin{array}{l}\text { Using wearable devices for assessing } \\
\text { the impacts of hair exposome in } \\
\text { Brazil }[40]\end{array}$ & 2019 & 7 & Sci Rep & Hair damage & $\begin{array}{l}\text { UVR, temperature, } \\
\text { humidity, ozone, } \\
\text { pollution and } \\
\text { chemicals }\end{array}$ \\
\hline $\begin{array}{l}\text { The exposome in atopic dermatitis } \\
\text { [41] }\end{array}$ & 2020 & 36 & Allergy & $\mathrm{AD}$ & $\begin{array}{l}\text { UVR, temperature, } \\
\text { humidity, } \\
\text { pollution, water } \\
\text { hardness, } \\
\text { allergens, } \\
\text { microbiome, } \\
\text { nutrition }\end{array}$ \\
\hline $\begin{array}{l}\text { A review of protection against } \\
\text { exposome factors impacting facial } \\
\text { skin barrier function with } 89 \% \\
\text { mineralizing thermal water [ } 42]\end{array}$ & 2019 & 7 & $\begin{array}{l}J \text { Cosmet } \\
\text { Dermatol }\end{array}$ & Skin aging & $\begin{array}{l}\text { Solar radiation, } \\
\text { pollution, } \\
\text { tobacco, } \\
\text { nutrition, stress, } \\
\text { sleep deprivation, } \\
\text { cosmetics }\end{array}$ \\
\hline $\begin{array}{l}\text { Leveraging multi-layered "omics" } \\
\text { data for atopic dermatitis: a road } \\
\text { map to precision medicine [43] }\end{array}$ & 2018 & 26 & Front Immunol & $\mathrm{AD}$ & - \\
\hline $\begin{array}{l}\text { Vichy thermal spring water } \\
\text { (VTSW), a cosmetic ingredient of } \\
\text { potential interest in the frame of } \\
\text { skin ageing exposome: an in vitro } \\
\text { study [44] }\end{array}$ & 2018 & 5 & Int J Cosmet Sci & Skin aging & - \\
\hline $\begin{array}{l}\text { The influence of exposome on acne } \\
{[45]}\end{array}$ & 2018 & 36 & $\begin{array}{l}J \text { Eur Acad } \\
\text { Dermatol } \\
\text { Venereol }\end{array}$ & Acne & $\begin{array}{l}\text { Nutrition, } \\
\text { psychological \& } \\
\text { lifestyle, } \\
\text { occupational, } \\
\text { pollution, } \\
\text { medication, } \\
\text { climatic factors }\end{array}$ \\
\hline
\end{tabular}


Table 1 continued

\begin{tabular}{|c|c|c|c|c|c|}
\hline Study title & Year & $\begin{array}{l}\text { Total } \\
\text { number } \\
\text { of } \\
\text { citations }\end{array}$ & Journal & Disease $(\mathbf{s})$ analysed & $\begin{array}{l}\text { Exposome factors } \\
\text { analysed }\end{array}$ \\
\hline $\begin{array}{l}\text { External exposome and allergic } \\
\text { respiratory and skin diseases [46] }\end{array}$ & 2018 & 71 & $\begin{array}{l}\text { J Allergy Clin } \\
\text { Immunol }\end{array}$ & $\begin{array}{l}\text { Respiratory allergies } \\
\text { and } \mathrm{AD}\end{array}$ & $\begin{array}{l}\text { Pollution, dust, } \\
\text { aeroallergens, } \\
\text { climate, } \\
\text { microbiome }\end{array}$ \\
\hline The skin aging exposome [47] & 2017 & 223 & $J$ Dermatol Sci & Skin aging & $\begin{array}{l}\text { Solar radiation, } \\
\text { pollution, } \\
\text { tobacco, } \\
\text { nutrition, } \\
\text { psychological } \\
\text { stress, sleep } \\
\text { deprivation, } \\
\text { temperature, } \\
\text { cosmetics }\end{array}$ \\
\hline
\end{tabular}

$A D$ Atopic dermatitis, $I R A$ infrared $\mathrm{A}, I R R$ infrared radiation, $N B-V B$ narrow-band ultraviolet $\mathrm{B}, N M S C$ non-melanoma skin cancer, $U V A$ ultraviolet $\mathrm{A}, U V R$ ultraviolet radiation, $V L$ visible light

et al. investigated the effects of both the external and internal exposome on respiratory allergies and $\mathrm{AD}$ [46]. These authors stratified the external exposome into nonspecific factors (climate, biodiversity, socioeconomic factors) and specific external factors (e.g. allergens, pollution and diet) [46]. Similar to this model, Stefanovic et al. reviewed the influential role of exposome factors in the aetiology and clinicopathological diversity seen in $\mathrm{AD}$ patients, highlighting several multi-level exposome manipulation approaches from the population to individuals as preventative strategies and proposing future directions for exposome characterization and modification [41]. Sözener et al. discussed the harmful effects of environmental factors, including allergens, pollution and plastics, on epithelial barrier integrity and partly explained how they can trigger barrier disruption and tissue inflammation, leading to the appearance of atopic and also respiratory and gut diseases [33]. Piquero-Casals et al. reviewed the role of UVR and the exposome in the aetiology of $\mathrm{AD}$, as well as the role of adequate photoprotection [28].

\section{Acne}

Dréno et al. were the pioneers in implementing this concept on acne and classified the impact of exposome factors by means of a review of the following six main categories: nutrition, medication, occupational factors (including cosmetics, pollutants, climatic factors) and psychological and lifestyle factors [45]. Data from an international survey added new evidence and confirmed the assumptions made in the literature review mentioned above [35].

\section{Psoriasis}

Damiani et al. addressed the psoriasis exposome by means of a review focused on the skin-microbiome-gut-nutrient interaction and suggested that diet could be modulating the gut microbiome and that the latter, in turn, could be modulating the systemic inflammatory response in the body [36]. 


\section{Rosacea}

Morgado-Carrasco et al. described the aetiology of rosacea with an emphasis on the role of UVR and exposome and explained how several environmental factors, such as UV light, diverse microorganisms, air pollution, tobacco smoking, nutrition and psychological stress trigger or worsen this disorder [27].

\section{Miscellaneous}

Passeron et al. reviewed the impact of exposome factors, including solar exposure, air pollution, hormones, nutrition and psychological factors, on skin aging and other skin pathologies, such as $\mathrm{AD}$, psoriasis, acne and rosacea [31]. Pacifico et al. evaluated the clinical outcomes of vegan, vegetarian and omnivore psoriatic patients undergoing ultraviolet $\mathrm{B}$ phototherapy and found that vegetarians consume foods containing photosensitizers capable of triggering phytophotodermatitis and that vegans have a higher risk of severe erythema [23]. Two meteorotropic studies assessed the real-life exposure conditions during routine daily activities on hair fibres and skin, carried out in Rio de Janeiro, by using multiple sensors to capture UVR, temperature, relative humidity, air pollution and ground level ozone levels [24, 40]. Damevska et al. reviewed qualitative and quantitative skin exposure assessment methodologies to air pollution [39], and subsequently published a second review focusing on how air pollution triggers or aggravates dermatoses [22]. Apenzeller et al. proposed hair biomonitoring as an alternative to biological fluids for assessing chronic exposure to environmental factors since hair analysis gives access to information covering a much wider temporal window than urine and blood [32]. These authors also discussed further approaches and perspectives to characterize and treat the skin exposome [32].

\section{Social and Intellectual Interactions in the "Skin Exposome" Documents}

Based on "skin exposome" documents and with the aim of identifying the relationship between the most salient authors, their publications and the most relevant references in their works, we constructed a three-field plot showing the flow of information among them. The most prolific authors identified in our three-field plot were A Bouloc, J Krutmann, T Passeron, CC Zouboulis, ML Andersen and $\mathrm{R}$ Katta, as well as many others (Fig. 4). The cited references shown in this three-field plot include the first definition of the exposome concept [8] and a later reworked definition [10]. The remaining cited references include the first publication of the exposome in dermatology and several articles which focus particularly on the consequences and clinical impact of pollution on the skin, the effects of UVR and infrared radiation and the impact of other exposome factors on skin aging, acne, psoriasis and other skin-related disorders.

\section{DISCUSSION}

Since publication of the exposome concept in 2005 , there has been a steady increase in the number of publications associated with this concept (Fig. 1), especially in the fields of environmental sciences and toxicology where aging, cancer and respiratory allergies are the most impacted diseases (Figs. 2, 3). Assuming that the skin provides an opportunity to link exposure to biological response, it is surprising that the first article in the field of dermatology related to the skin aging exposome was not published until 2017 [47]. After this signal event, increasingly more research groups in dermatology have assessed the impact of environmental factors on skin, especially on skin aging $[26,30,31,34$, $37,38,42,44]$, psoriasis $[31,36]$, acne $[31,35,45], \mathrm{AD}[31,33,41,43,46]$ and rosacea [27], through an exposome approach. Clearly, skin aging and $\mathrm{AD}$ have been greatly impacted by the exposome concept, while skin cancer has been less impacted by this new approach, leading us to review here the influential role of the exposome in non-melanoma skin cancers, specifically actinic keratosis, squamous cell carcinoma and Bowen's disease. The exposome concept will bring new insights and consolidate a new era of research since most skin disorders are the result of a complex interaction between genetics and the environment [1-4]. In addition, the holistic part of the exposome concept 


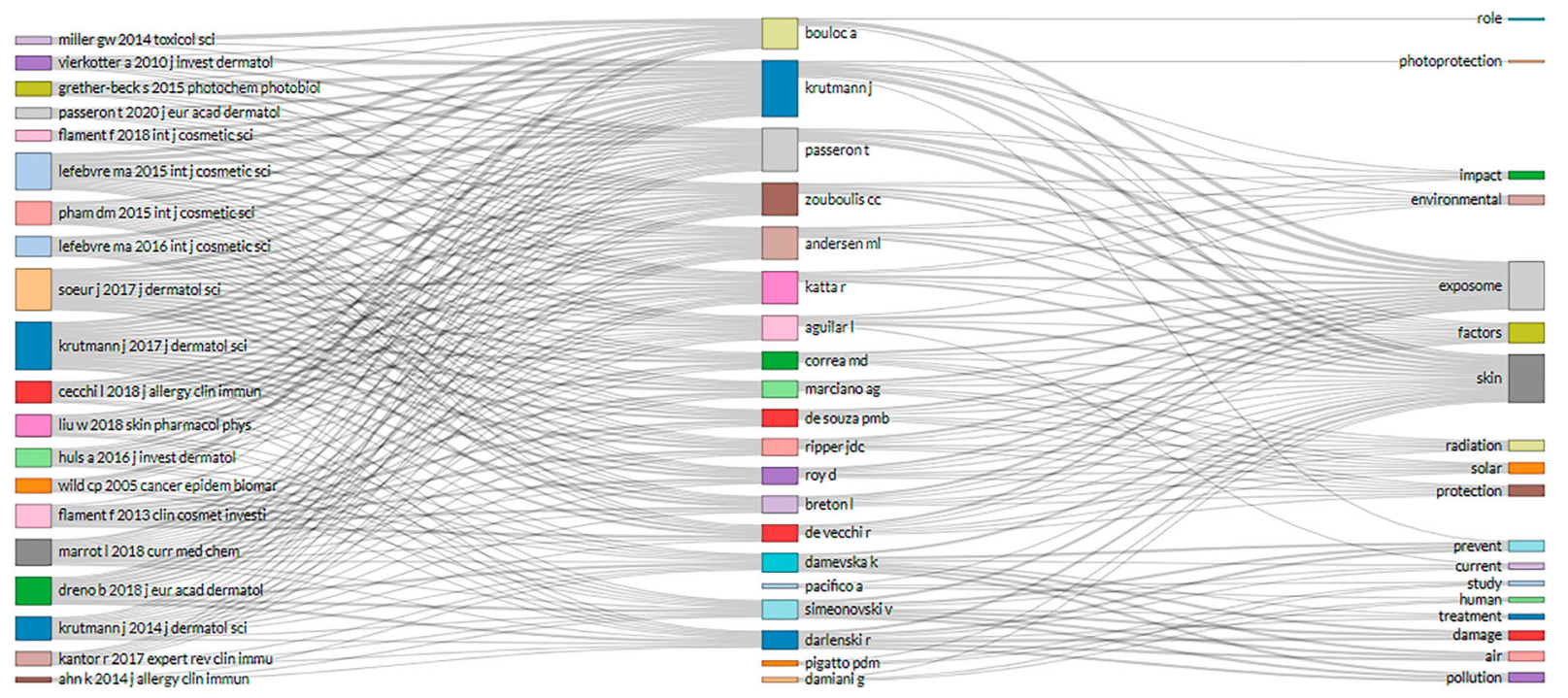

Fig. 4 Three-fields plot showing the relationship between references (left column), salient authors (middle column) and titles (right column) in the "skin exposome" documents

could help to unravel the complex interactions which occur between the different exposome factors and their associated biological consequences.

Historically, the impact of the exposome factors on skin has been studied separately, and the molecular crosstalk between the distinct factors and biological response is poorly understood, as suggested by Krutmann and colleagues in the skin aging example [47]. When the impact of a number of exposome factors combined is studied, the biological results and consequences cannot be explained by the cumulative effect of each one separately, suggesting there might be a synergistic effect and molecular crosstalk between them that can only be elucidated through an exposome approach. In addition to the environmental interactions, exposome approaches should be studied and interpreted against the genetic background of the population to create the most accurate disease prediction model as possible, thereby enabling the design of tailormade prevention strategies. Most of the skin exposome studies published to date (Table 1) [22-47] are reviews that examine studies evaluating the effect of exposome factors individually; consequently, interaction effects are probably missed and not taken into consideration. There has been no environment-wide association study (EWAS) published to date that evaluates the link between environmental variables and skin disorders in a high-throughput and unbiased manner, which would help to elucidate how exposure modulates pleiotropy, as in the example of diabetes [48]. In addition, most studies do not consider the environmental exposure effect of the prenatal period, and such assessment could provide insight into disease development since developmental periods in early life may be particularly vulnerable to the impact of environmental exposure [49], suggesting a developmental programming of the foetal phenotype through epigenetic modifications in order to prepare the individual for the predicted environment [50, 51]. In fact, the term "pregnancy" has been one of the most recurrent author keywords in the "exposome" publications (Fig. 3). Furthermore, there is an urgent need in dermatology to use integrative multi-omics approaches, as in the example of $\mathrm{AD}$ [43], which may bring new insight into the effect and interaction of all exposome factors and the associated human body response. Several publications on the exposome were related to both $\mathrm{AD}$ and allergies [33, 46]. This relationship could be explained by the atopic march, a model that explains the progression of allergies from $\mathrm{AD}$ to allergic asthma, allergic rhinitis and also food allergies, as all three (skin, 
trachea and gut) are epithelial barriers exposed to environmental factors against the same genetic and immunological background [52]. In the case of psoriasis, a strong relationship with nutrients and the microbiome has been found since diet appears to play an important role in this disease and the gut microbiota could modulate systemic inflammatory disease [36].

\section{Study Limitations and Strengths}

This bibliometric analysis only offers a snapshot of what has been published until now, and no assertions can be made about the exposome and its impact on dermatology in the long run. In addition, the main limitation of this review is that only one database was used for data retrieval. Nevertheless, the WOS Core Collection platform is a curated collection of over 21,000 peer-reviewed, high-quality scholarly journals published worldwide. It is a selective, structured and balanced database with complete citation linkages and metadata with a wide range of information.

\section{CONCLUSIONS}

In conclusion, we believe that the exposome approach, which has had a low impact on dermatology in recent decades, is starting to quickly gain interest and will probably bring new insight into the understanding of the complex interactions between environmental factors and the associated biological responses. This great challenge could be overcome with "Big Data" analysis and integrative multi-omics; tailored prevention strategies could then be devised from these data and provide help for patients suffering from skin disorders.

\section{ACKNOWLEDGEMENTS}

Funding. ISDIN provided funding for the journals Rapid Service Fee. No other funding was received for this study.
Authorship. All named authors meet the International Committee of Medical Journal Editors (ICMJE) criteria for authorship for this article, take responsibility for the integrity of the work as a whole, and have given their approval for this version to be published.

Author Contributions. All authors contributed to the study conception and design. Material preparation, data collection and analysis were performed by all authors. The first draft of the manuscript was written by Manuel Molina-García, and all authors commented on previous versions of the manuscript. All authors read and approved the final manuscript.

Disclosures. Susana Puig and Manuel Molina declare that they have nothing to disclose. Corinne Granger and Carles Trullàs are employees of ISDIN.

Compliance with Ethics Guidelines. This article is based on previously conducted studies, and does not involve any new studies of human or animal subjects performed by any of the authors.

Data Availability. Data sharing is not applicable to this article as no datasets were generated or analysed during the current study.

Open Access. This article is licensed under a Creative Commons Attribution-NonCommercial 4.0 International License, which permits any non-commercial use, sharing, adaptation, distribution and reproduction in any medium or format, as long as you give appropriate credit to the original author(s) and the source, provide a link to the Creative Commons licence, and indicate if changes were made. The images or other third party material in this article are included in the article's Creative Commons licence, unless indicated otherwise in a credit line to the material. If material is not included in the article's Creative Commons licence and your intended use is not permitted by statutory regulation or exceeds the permitted use, you will need to obtain permission directly from the copyright holder. To view a copy of this licence, 
visit http://creativecommons.org/licenses/bync/4.0/.

\section{REFERENCES}

1. Otsuka A, Nomura T, Rerknimitr P, Seidel J, Honda $\mathrm{T}$, Kabashima K. The interplay between genetic and environmental factors in the pathogenesis of atopic dermatitis. Immunol Rev. 2017;278:246-62.

2. Cust AE. Melanoma-role of the environment and genetics. Photochem Photobiol Sci. 2018;17(12): 1853-60.

3. Krueger G, Ellis CN. Psoriasis-recent advances in understanding its pathogenesis and treatment. J Am Acad Dermatol. 2005;53:S94-100.

4. McCullough JL, Kelly KM. Prevention and treatment of skin aging. Ann NY Acad Sci. 2006;1067: 323-31.

5. Schwartz D, Collins F. Medicine. Environmental biology and human disease. Science. 2007;316: 695-6.

6. Lander ES, Linton LM, Birren B, et al. International human genome sequencing consortium. Initial sequencing and analysis of the human genome. Nature. 2001;409:860-921.

7. Venter JC, Adams MD, Myers EWG, et al. The sequence of the human genome. Science. 2001;291: 1304-51.

8. Wild CP. Complementing the genome with an "exposme": the outstanding challenge of environmental exposure measurement in molecular epidemiology. Cancer Epidemiol Biomarkers. 2005;14: 1847-50.

9. Wild CP. The exposome: from concept to utility. Int J Epidemiol. 2012;41:24-32.

10. Miller GW, Jones DP. The nature of nurture. Refining the definition of the exposome. Toxicol Sci. $2014 ; 137(1): 1-2$.

11. Polefka TG, Meyer TA, Agin PP, Bianchini RJ. Effects of solar radiation on the skin. J Cosmet Dermatol. 2012;11:134-43.

12. Balato N, Megna M, Ayala F, Balato A, Napolitano M, Patruno C. Effects of climate changes on skin diseases. Expert Rev Anti Infect Ther. 2014;12(2):171-81.

13. Araviiskaia E, Berardesca E, Bieber T, et al. The impact of airborne pollution on skin. J Eur Acad Dermatol Venereol. 2019;33:1496-505.
14. Pappas A, Liakou A, Zouboulis CC. Nutrition and skin. Rev Endocr Metab Disord. 2016;17(3):443-8.

15. Ortiz A, Grando S. Smoking and the skin. Int J Dermatol. 2012;51:250-62.

16. Zouboulis CC. The human skin as a hormone target and an endocrine gland. Hormones. 2004;3(1):9-26.

17. Zeeuwen PLJM, Kleerebezem M, Timmerman HM, Schalkwijk J. Microbiome and skin diseases. Curr Opin Allergy Clin Immunol. 2013;13(5):514-20.

18. Orion E, Wolf R. Psychological stress and epidermal barrier function. Clin Dermatol. 2012;30:280-5.

19. R Core Team (2020). R: a language and environment for statistical computing. Vienna: R Foundation for Statistical computing. https://www.Rproject.org/. Accessed Nov 2021.

20. Aria M, Cuccurullo C. bibliometrix: an R-tool for comprehensive science mapping analysis. J Informetr. 2017;11(4):959-75.

21. Van Eck NJ, Waltman L. Software survey: VOS viewer, a computer program for bibliometric mapping. Scientometrics. 2010;84(2):523-38.

22. Damevska K, Simeonovski V, Darlenski R, Damevska S. How to prevent skin damage from air pollution part 2: current treatment options. Dermatol Ther. 2021;34:e15132.

23. Pacifico A, Conic RR, Cristaudo A, et al. Diet-related phototoxic reactions in psoriatic patients undergoing photherapy: results from a multicenter prospective study. Nutrients. 2021;13:2934.

24. Correa MP, Marciano AG, Carvalho VS, et al. Exposome extrinsic factors in the tropics: The need for skin protection beyond solar UV radiation. Sci Total Environ. 2021;782:146921.

25. Passeron T, Zouboulis CC, Tan J, et al. Adult skin acute stress responses to short-term environmental and internal aggression from exposome factors. J Eur Acad Dermatol Venereol. 2021;35:1963-75.

26. Krutmann J, Schalka S, Watson RE, Wei L, Morita A. Daily photoprotection to prevent photoaging. Photodermatol Photoimmunol Photomed. 2021;00:1-8.

27. Morgado-Carrasco D, Granger C, Trullas C, PiqueroCasals J. Impact of ultraviolet radiation and exposome on rosacea: Key role of photoprotection in optimizing treatment. J Cosmet Dermatol. 2021;20(11):3415-21.

28. Piquero-Casals J, Carrascosa JM, Morgado-Carrasco $\mathrm{D}$, et al. The role of photoprotection in optimizing 
the treatment of atopic dermatitis. Dermatol Ther (Heidelb). 2021;11:315-25.

29. Jaiswal SK, Agarwal SM, Thodum P, Sharma VK. SkinBug: an artificial intelligence approach to predict human skin microbiome-mediated metabolism of biotics and xenobiotics. iScience. 2021;24(1): 101925 .

30. Percoco G, Patatian A, Eudier F, et al. Impact of cigarette smoke on physical-chemical and molecular proprieties of human skin in an ex vivo model. Exp Dermatol. 2021;30(11):1610-8.

31. Passeron T, Krutmann J, Andersen ML, Katta R, Zouboulis CC. Clinical and biological impact of the exposome on the skin. J Eur Acad Dermatol Venereol. 2020;34(4):4-25.

32. Apenzeller BMR, Chadeau-Hyam M, Aguilar L. Skin exposome science in practice: current evidence on hair biomonitoring and future perspectives. J Eur Acad Dermatol Venereol. 2020;34(4):26-30.

33. Sözener ZC, Cevhertas L, Nadeau K, Akdis M, Akdis CA. Environmental factors in epithelial barrier dysfunction. J Allergy Clin Immunol. 2020;145: 1517-28.

34. Buendía-Eisman A, Prieto L, Abarquero M, AriasSantiago S. Study of the exposome ageing-related factors in the Spanish population. Acta Derm Venereol 100(10): adv00153

35. Dréno B, Shourick J, Kerob D, Bouloc A, Taïeb C. The role of exposome in acne: results from an international patient survey. J Eur Acad Dermatol Venereol. 2020;34:1057-64.

36. Damiani G, Bragazzi NL, McCormick TS, et al. Gut microbiota and nutrient interactions with skin in psoriasis: a comprehensive review of animal and human studies. World J Clin Cases. 2020;8(6): 1002-12.

37. Grandi C, D'Ovidio MC. Balance between health risks and benefits for outdoor workers exposed to solar radiation: an overview on the role of near infrared radiation alone and in combination with other solar spectral bands. Int J Environ Res Public Health. 2020;17:1357.

38. Khmaladze I, Leonardi M, Fabre S, Messaraa C, Mavon A. The skin interactome: a holistic, "genome-microbiome-exposome" approach to understand and modulate skin health and aging. Clin Cosmet Investig Dermatol. 2020;13:1021-40.

39. Damevska K, Boev B, Mirakovski D, Petrov A, Darlenski R, Simeonovski V. How to prevent skin damage from air pollution: Part 1: Exposure assessment. Dermatol Ther. 2020;33:e13171.
40. De Vecchi R, da Silveira Carvalho Ripper J, Roy D et al. Using wearable devices for assessing the impacts of hair exposome in Brazil. Sci Rep. 2019;9: 13357.

41. Stefanovic N, Flohr C, Irvine AD. The exposome in atopic dermatitis. Allergy. 2020;75:63-74.

42. Salsberg J, Andriessen A, Abdulla S, et al. A review of protection against exposome factors impacting facial skin barrier function with $89 \%$ mineralizing thermal water. J Cosmet Dermatol. 2019;18(3): 815-20.

43. Ghosh D, Bernstein JA, Hershey GKK, Rothenberg ME, Mersha TB. Leveraging multilayered "omics" data for atopic dermatitis: a road map to precision medicine. Front Immunol. 2018;9:2727.

44. Tacheau C, Weisgerber F, Fagot D, et al. Vichy thermal spring water (VTSW), a cosmetic ingredient of potential interest in the frame of skin aging exposome; an in vitro study. Int J Cosmet Sci. $2018 ; 40(4): 377-87$

45. Dréno B, Bettoli V, Araviiskaia E, Sanchez Viera M, Bouloc A. The influence of exposome on acne. J Eur Acad Dermatol Venereol. 2018;32:812-9.

46. Cecchi L, D'Amato G, Annesi-Maesano I. External exposome and allergic respiratory and skin diseases. J Allergy Clin Immunol. 2018;141(3):846-57.

47. Krutmann J, Bouloc A, Sore G, Bernard BA, Passeron $\mathrm{T}$. The skin aging exposome. J Dermatol Sci. 2017;85:152-61.

48. Patel CJ, Bhattacharya J, Butte AJ. An environmentwide association study (EWAS) on type 2 diabetes mellitus. PLoS One. 2010;5(5):e10746.

49. Vrijheid M, Slama R, Robinson O, et al. The human early-life exposome (HELIX): project rationale and design. Environ Health Perspect. 2014;122(6): 535-44.

50. Goyal D, Limesand SW, Goyal R. Epigenetic responses and the developmental origins of health and disease. J Endocrinol. 2019;242(1):T105-19.

51. Safi-Stibler S, Gabory A. Epigenetics and the developmental origins of health and disease: Parental environment signalling to the epigenome, critical time windows and sculpting the adult phenotype. Semin Cell Dev Biol. 2020;97:172-80. https://doi. org/10.1016/j.semcdb.2019.09.008.

52. Paller AS, Spergel JM, Mina-Osorio P, Irvine AD. The atopic march and atopic multimorbidity: many trajectories, many pathways. J Allergy Clin Immunol. 2018;143(1):46-55. 